\title{
Analysis models for variables associated with breastfeeding duration
}

\author{
Modelos de análise dos fatores associados à duração do aleitamento materno
}

Modelo de análisis de los factores asociados a la duración de la lactancia materna

Edson Theodoro dos S. Neto ${ }^{1}$, Eliana Zandonade ${ }^{2}$, Adauto Oliveira Emmerich ${ }^{3}$

\section{ABSTRACT}

Objective: To analyze the factors associated with breastfeeding duration by two statistical models.

Methods: A population-based cohort study was conducted with 86 mothers and newborns from two areas primary covered by the National Health System, with high rates of infant mortality in Vitória, Espírito Santo, Brazil. During 30 months, 67 (78\%) children and mothers were visited seven times at home by trained interviewers, who filled out survey forms. Data on food and sucking habits, socioeconomic and maternal characteristics were collected. Variables were analyzed by Cox regression models, considering duration of breastfeeding as the dependent variable, and logistic regression (dependent variables, was the presence of a breastfeeding child in different post-natal ages).

Results: In the logistic regression model, the pacifier sucking (adjusted Odds Ratio: 3.4; 95\%CI 1.2-9.55) and bottle feeding (adjusted Odds Ratio: 4.4; 95\%CI 1.6-12.1) increased the chance of weaning a child before one year of age. Variables associated to breastfeeding duration in the Cox regression model were: pacifier sucking (adjusted Hazard Ratio 2.0; 95\% CI 1.2-3.3) and bottle feeding (adjusted Hazard Ratio 2.0 ; 95\% CI 1.2-3.5). However, protective factors (maternal age and family income) differed between both models.

Conclusions: Risk and protective factors associated with cessation of breastfeeding may be analyzed by different models of statistical regression. Cox Regression Models are adequate to analyze such factors in longitudinal studies.

Key-words: maternal and child health; breast feeding; cohort studies.

Instituição: Departamento de Medicina Social da Universidade Federal do Espírito Santo (UFES), Vitória, ES, Brasil

'Doutor em Epidemiologia em Saúde Pública pela Fundação Oswaldo Cruz (Fiocruz), Rio de Janeiro, RJ, Brasil

2Doutora em Estatística pela Universidade de São Paulo (USP), São Paulo, SP, Brasil

${ }^{3}$ Pós-Doutor em Saúde Pública pela Fiocruz, Rio de Janeiro, RJ, Brasil
RESUMO

Objetivo: Analisar os fatores associados à duração do aleitamento materno por dois modelos de análise estatística.

Métodos: Um estudo de coorte populacional foi conduzido com 86 mães e crianças recém-nascidas originárias de duas áreas cobertas pela atenção primária do Sistema Único de Saúde, com altos indicadores de mortalidade infantil, em Vitória, Espírito Santo. Durante 30 meses, 67 (78\%) crianças e mães foram visitadas sete vezes nos domicílios por entrevistadores treinados, que preencheram formulários de pesquisa. Nas entrevistas, informações sobre hábitos de sucção e alimentares, além de características maternas e socioeconômicas foram coletadas. Em seguida, os dados foram processados e analisados pelos modelos de regressão de Cox, adotando-se como variável a duração do aleitamento materno, e de regressão logística, com variáveis dependentes relacionadas ao fato de a criança estar em aleitamento nos meses determinados.

Resultados: No modelo de regressão logística, a sucção de chupeta (Odds Ratio ajustada: 3,4; IC95\% 1,2-9,55) e o aleitamento artificial (Odds Ratio ajustada: 4,4; IC95\% 1,6-12,1) aumentaram as chances do desmame da criança antes de um ano de vida. As variáveis associadas à duração do aleitamento materno foram, no modelo de regressão de Cox, a sucção de chupeta (Hazard Ratio ajustada: 2,0; IC95\% 1,2-3,3) e o aleitamento artificial (Hazard Ratio ajustada: 2,0; IC95\% 1,2-3,5). Contudo, os fatores de proteção idade materna e renda familiar mensal diferiram entre os modelos.

\footnotetext{
Endereço para correspondência:

Edson Theodoro dos S. Neto

Rua Guilherme Bassini, 97

CEP 29030-015 - Vitória/ES

E-mail: edsontheodoro@uol.com.br

Fonte financiadora: Fundação de Apoio à Ciência e Tecnologia do Município de Vitória (Facitec)

Conflito de interesse: nada a declarar

Recebido em: 8/10/2012

Aprovado em: 22/2/2013
} 
Conclusões: Os fatores de risco e de proteção associados à interrupção do aleitamento materno podem ser analisados por diferentes modelos de análise estatística de regressão. Os modelos de regressão de Cox são apropriados para analisar tais fatores em estudos longitudinais.

Palavras-chave: saúde materno-infantil; aleitamento materno; estudos de coortes.

\section{RESUMEN}

Objetivo: Analizar los factores asociados a la duración de la lactancia materna por dos modelos de análisis estadístico.

Métodos: Un estudio de cohorte de población fue conducido con 86 madres y niños recién nacidos originarios de dos áreas cubiertas por la atención primaria del Sistema Único de Salud, con altos indicadores de mortalidad infantil, en Vitória, Espírito Santo (Brasil). Durante 30 meses, 67 (78\%) niños y madres fueron visitadas siete veces en los domicilios por entrevistadores entrenados, que rellenaron formularios de investigación. En las entrevistas, informaciones sobre hábitos de succión y alimentares, además de características maternas y socioeconómicas fueron recogidas. Enseguida, los datos fueron procesados y analizados por los modelos de regresión de Cox, adoptándose como variable la duración de la lactancia materna, y de regresión logística, con variables dependientes relacionadas al hecho del niño estar en lactancia los meses determinados.

Resultados: En el modelo de regresión logística, la situación del chupete (Odds Ratio ajustada: 3,4; IC95\% 1,2-9,55) y la lactancia artificial (Odds Ratio ajustada: 4,4; IC95\% 1,6-12,1) aumentaron las posibilidades del destete del niño antes de un año de vida. Teniendo en cuenta la duración de la lactancia materna, en el modelo de regresión de Cox, la succión de chupete (Hazard Ratio ajustada: 2,0; IC95\% 1,2-3,3) y la lactancia artificial (Hazard Ratio ajustada: 2,0; IC95\% 1,2-3,5) también se presentaron como factores de riesgo para el destete. Sin embargo, los factores de protección edad materna e ingresos familiares mensuales difirieron entre los modelos.

Conclusiones: Los factores de riesgo y de protección asociados a la interrupción de la lactancia materna pueden ser analizados por distintos modelos de análisis estadístico de regresión; sin embargo, los modelos de regresión de Cox se presentaron apropiados para analizar tales factores en estudios longitudinales.

Palabras clave: salud materno infantil; lactancia materna; estudio de cohortes.

\section{Introduction}

When breastfeeding duration had its importance recognized by the World Health Organization (WHO) ${ }^{(1)}$, studies on the factors associated with exclusive and total breastfeeding duration has intensified in the last years. The knowledge on the effects of breastfeeding on children's health is based on scientific evidence showing its capacity to prevent morbidity and mortality from diarrhea in the first two years of life ${ }^{(2)}$. Additionally, throughout life, breastfeeding duration is associated with lower levels of cholesterol and cardiovascular diseases in adulthood ${ }^{(3)}$. Given the relevance of breastfeeding for the conjunctural development of the human being, both in childhood and in adulthood, empirical studies have been conducted to explain the possible risk and protective factors related to the duration of this practice ${ }^{(4)}$.

Studies with cohort ${ }^{(5)}$ and sectional ${ }^{(6-8)}$ epidemiological design, as well as clinical trials ${ }^{(9)}$, have been useful to measure what determines early weaning. In these investigations, statistical analyses have varied between and within the types of study, since the techniques include univariate, bivariate and multivariate analyses ${ }^{(4)}$. Logistic regression models (LRMs) and Cox regression models (CRMs) have been used to adjust results for variables and consider the influence of confounding factors.

LRMs may be used considering total breastfeeding duration in a fragmented way, i.e., by dividing breastfeeding duration into fixed intervals of children's life ${ }^{(6,8)}$. In this sense, these models are limited, because they analyze longitudinal information as if it was cross-sectional, although being useful when one analyzes the fact that a child is breastfed at a specific lifetime. In CMRs, breastfeeding duration is related to child's survival until weaning ${ }^{(5,7)}$, considered month to month. These models are appropriate for the analysis of longitudinal data and should not be used in the analysis of crosssectional data, when the history of the outcome (weaning) is not known. However, it is suggested that these analysis techniques may differ among themselves with regard to the determination of risk and protective factors of breastfeeding.

Therefore, the aim of this study was to analyze the factors associated with breastfeeding duration by two regression models in a cohort of mothers and children that were followed for 30 months in Vitória, Espírito Santo, Brazil.

\section{Method}

A cohort study was conducted with 86 mothers and newborns, during 30 months, including all babies from zero to three months living in two areas covered by the 
Health Family Program from the National Health System in Vitória. These two areas were chosen because, in 2001, they had indicators of infant mortality higher than those of the city rate $(13.49 / 1,000 \text { live births })^{(10)}$.

Sample size was calculated in order to estimate a proportion, considering the data provided by the Brazilian Ministry of Health regarding the size of the population of live births in 2001 in the city of Vitória (4,521 children) and the prevalence of total breastfeeding in the age from 151 to 180 days for the year 1999 (74.8\%), considering an accuracy of $10 \%$ and a significance level of $5 \%$. Sample size was estimated in 73 children. Therefore, the sample of 86 children allowed for a $18 \%$ safety margin to account for possible losses to follow-up.

The period for inclusion in the study group lasted from November 2003 to May 2004, moment when health community workers referred the babies at the predetermined age to four dental students at Universidade Federal do Espírito Santo who, after being trained and divided into pairs, observed the follow-up home visits made to the study subjects. All mothers and children approached were included in the study, since there were no impeditive factors justifying their exclusion. This same team followed the participants for 18 months; then, another team of similar composition completed the follow-up, after specific training.

Mothers were invited to participate in the research and received information on the nature of the study and the frequency of the consecutive home visits. Without exception, all visited mothers spontaneously accepted to participate, signed a free and informed consent, and were interviewed to fill out a form.

Visits took place according to a schedule (initially every three months, later every six months) and served as observational control of the first visit. At each visit, a new form was filled out based on observation and on a structured interview applied to mothers.

Data collection by home visits finished in June 2006, amounting to seven home visits. The study period covered the breastfeeding duration recommended by the WHO, since the children were, on average, 29.4 \pm 2.5 months old at the end of the study.

Breastfeeding was considered according to the definitions of breastfeeding categories recommended by $\mathrm{OMS}^{(1,11)}$. For the accurate definition of this variable, at each visit mothers were asked whether they breastfed their child or used feeding bottles or other artificial nipples for feeding (such as chuquinha).

The variables on nutritive and non-nutritive sucking habits were measured by the duration of finger sucking, duration of pacifier sucking, and duration of bottle feeding.
These variables were defined by asking at each visit whether the child had the habit. If yes, records were made of when it started and, in case the habit had been discontinued, when it had stopped. Then, duration was calculated.

At each visit, the mother was asked about the introduction of any food of any nature in the child's diet: smashed fruits, vegetables, or even industrialized foods. If yes, records were made of the month in which the child had started this eating habit and literally what food had been used during the previous 24 hours.

Socioeconomic variables were collected at the first home visit. The following data were recorded: maternal education level, family income in minimum wages, paternal occupation, maternal occupation, maternal age, marital status, marital stability, number of people living in the same household, finishing of the house, number of rooms, number of children below five years of age, number of live births of the mother, number of siblings of the child (considering the same mother), and interval between pregnancies.

Statistical analyses were performed after reviewing and adapting the database applied in the Statistical Package for the Social Sciences (SPSS) for Windows software, version 12.0, selecting the variables of interest. The significance level was set at $5 \%$ for all the tests.

LRMs were built from the analyses, considering all study variables and the dichotomized breastfeeding variables, and calculating the association with the Yates chi-square test. In LRM (1), exclusive breastfeeding until three months was used as dependent variable; in LRM (2), breastfeeding until six months; in LRM (3), breastfeeding until 12 months. Independent variables were those with a $p$-value lower than or equal to 0.10 at the initial analysis. For independent variables with strong association between themselves (e.g., pacifier use until the first month, until the third month, and until the first year), only one of them was used in the model, i.e., that with the earlier onset of the risk factor and higher unadjusted Odds Ratio with regard to the dependent variable. The unconditional Stepwise forward logistic regression model was applied for the automatic selection of variables, which tests the entry of variables with statistical significance by a score and remove them using the likelihood ratio, based on maximum partial likelihood estimates. Significance level was set at 0.10 for the entry and 0.20 for the exit of variables in the model.

CRMs were built from the bivariate analysis of survival, whose variable of interest was breastfeeding duration (in months) and the independent variables were the remaining study variables. Kaplan-Meier survival curve was calculated from the maximum duration of breastfeeding, and the 
log-rank test was used to compare the curves according to the subgroups. Then, CRMs were obtained by including variables with a $p$-value lower than or equal to 0.10 in the log-rank test. For independent variables with strong association between themselves (e.g., pacifier use until the first month, until the third month, and until the first year), only one of them was used in the model. In CRM (1), bottle feeding and pacifier sucking occurred earlier; in CRM (2), it was possible to find variables with higher association strength in the log-rank test; in CRM (3), bottle feeding and pacifier use occurred later.

The research protocol was submitted to the Research Ethics Committee of the Biomedical Center at Universidade Federal do Espírito Santo and approved in the $43^{\text {rd }}$ ordinary meeting of $25^{\text {th }}$ June, 2003, under registration no. 20/2003.

\section{Results}

At the initial visit, 86 children $(100 \%)$ were analyzed, with a mean age ranging from $1.58 \pm 1.05$ months. At the second visit, 81 (94.1\%) were approached, with a mean age of $4.89 \pm 1.55$ months. At the third and forth visits, participants amounted to $79(91.8 \%)$ children, with means ages ranging from $7.39 \pm 1.56$ and $11.61 \pm 2.16$ months, respectively. At the fifth visit, $76(88.4 \%)$ children were found, and the group had a mean age of $16.39 \pm 2.88$ months, while, at the sixth visit, $66(76.7 \%)$ children participated, and mean age was $21.92 \pm 3.03$ months. At the seventh visit, 67 (77.9\%) children participated, since one child returned to household, yielding a mean age of $29.42 \pm 2.49$ months. Losses to followup were motivated by change of address and by the failure to locate the household after at least three attempts. Mean for total breastfeeding duration was 15 months (95\% CI 13-18), and median was also 15 months (95\% CI 10-20).

LRM analyses, shown in Table 1 , allowed to detect the risk factors associated with cessation of breastfeeding, adjusted for all statistically significant factors, evidencing the interaction of these factors. The onset of pacifier use until the first month represented a risk factor in all breastfeeding patterns analyzed. Bottle feeding until the first month of life also represented a risk factor for cessation of breastfeeding in LRMs (2) and (3).

Regarding bottle use, which is generally associated with bottle feeding, the choice for the use of only one of these variables allowed to represent nutritive sucking habits without being detrimental to the analysis model. The variable use of other artificial nipples before six months remained significantly associated only with cessation of breastfeeding, while teeth eruption before six months posed risk for cessation of breastfeeding only at the sixth month of life. The only protective factor was maternal age equal to or higher than 35 years.

In Table 2, regardless of the fact that the onset of bottle feeding or bottle use was early or late, all variables had significance values lower than $5 \%$. On the other hand, variables related to pacifier sucking showed higher association strength as the habit was established later.

In Table 3, as for CRM (1), the onset of bottle feeding until the first month of life was the only variable that remained significant as a risk factor for cessation of breastfeeding; on the other hand, lower family income remained as a protective factor. In CRM (2), the onset of bottle feeding until the first year and the onset of pacifier sucking remained as risk factors associated with cessation of breastfeeding, whereas lower family income showed to be a protective factor. In CRM (3), the onset of pacifier use until the sixth month of life was the only variable that was consolidated as a risk factor for reduction in breastfeeding duration. Income lower than or equal to two minimum wages remained as a protective factor for breastfeeding maintenance.

Figure 1 shows protective and risk factors and confidence intervals associated with breastfeeding duration, considering adjusted Hazard Ratio and Odds Ratio values. Only protective factors differed between models. Age equal to or higher than 35 years appeared only in LRM (3), whereas monthly family income was found only in CRMs.

\section{Discussion}

In cohort studies, in which data collection took place at determined time points, logistic regression analyses are performed by dividing breastfeeding durations into intervals that are processed separately, as if each time point was an individual cross-sectional study. In CRMs, analyses considered total breastfeeding duration, with the answer being the time until the occurrence of the event (cessation of breastfeeding), adjusted for co-variables. In both models, the purpose is to investigate the combined effect of independent variables, to neutralize confounding effects, and to adjust the final results for Odds Ratio and Hazard Ratio.

The results for LRM (1) with regard to exclusive breastfeeding, at the first three months of life, reinforce that pacifier use and the introduction of other artificial nipples until the first month of life are crucial to increase the risk 
Table 1 - Factors associated with exclusive breastfeeding and breastfeeding duration in bivariate analyses and in the three logistic regression models. Vitória, Brazil, 2007

\begin{tabular}{|c|c|c|c|c|c|c|c|c|}
\hline & Yes (\%) & No (\%) & $p$-value & OR & $95 \% \mathrm{Cl}$ & $p$-value & AOR & $95 \% \mathrm{Cl}$ \\
\hline \multicolumn{9}{|c|}{ Breastfeeding $>3$ months $(n=81)-L R M(1)$} \\
\hline $\begin{array}{l}\text { Pacifier sucking } \\
\text { (onset until } 1^{\text {st }} \text { month) }\end{array}$ & $2(12.5)$ & $\begin{array}{c}27 \\
(41.5)\end{array}$ & & & & & & \\
\hline $\begin{array}{l}\text { Other artificial nipples } \\
\text { (onset until } 6^{\text {th }} \text { month) }\end{array}$ & $1(6.3)$ & $\begin{array}{c}37 \\
(56.9)\end{array}$ & 0.001 & 19.82 & $2.47-426.13$ & 0.005 & 20.517 & $2.51-168.77$ \\
\hline \multicolumn{9}{|c|}{ Breastfeeding $\geq 6$ months $(n=80)-$ LRM (2) } \\
\hline $\begin{array}{l}\text { Bottle feeding } \\
\text { (onset until } 1^{\text {st }} \text { month) }\end{array}$ & $12(20.0)$ & $\begin{array}{c}15 \\
(75.0)\end{array}$ & & & & & & \\
\hline $\begin{array}{l}\text { Bottle feeding } \\
\text { (onset until } 6^{\text {th }} \text { month) }\end{array}$ & $36(60.0)$ & $\begin{array}{c}20 \\
(100 .)\end{array}$ & 0.002 & - & Indefinido & & & \\
\hline $\begin{array}{l}\text { Pacifier sucking } \\
\text { (onset until } 1^{\text {st }} \text { month) }\end{array}$ & $16(26.7)$ & $\begin{array}{c}13 \\
(65.0)\end{array}$ & 0.005 & 5.11 & $1.54-17.48$ & 0.037 & 4.092 & $1.09-15.34$ \\
\hline $\begin{array}{l}\text { Pacifier sucking } \\
\text { (onset until } 3^{\text {rd }} \text { month) }\end{array}$ & $22(36.7)$ & $\begin{array}{c}14 \\
(77.8)\end{array}$ & 0.005 & 6.05 & $1.58-25.13$ & & & \\
\hline $\begin{array}{l}\text { Pacifier sucking } \\
\text { (onset until } 6^{\text {th }} \text { month) }\end{array}$ & $26(43.3)$ & $\begin{array}{c}15 \\
(83.3)\end{array}$ & 0.006 & 6.54 & $1.53-32.01$ & & & \\
\hline $\begin{array}{l}\text { Bottle use } \\
\text { (onset until } 1^{\text {st }} \text { month) }\end{array}$ & $14(23.30$ & $\begin{array}{c}15 \\
(75.0)\end{array}$ & 0.000 & 9.86 & $2.69-38.31$ & & & \\
\hline $\begin{array}{l}\text { Bottle use } \\
\text { (onset until } 3^{\text {rd }} \text { month) }\end{array}$ & $19(31.7)$ & $\begin{array}{c}18 \\
(100 .)\end{array}$ & 0.000 & - & Indefinido & & & \\
\hline $\begin{array}{l}\text { Bottle use } \\
\text { (onset until } 6^{\text {th }} \text { month) }\end{array}$ & $35(58.3)$ & $\begin{array}{c}18 \\
(100 .)\end{array}$ & 0.002 & - & Indefinido & & & \\
\hline $\begin{array}{l}\text { Teeth eruption } \\
\text { (until } 6^{\text {th }} \text { month) }\end{array}$ & $24(40.0)$ & $3(15.8)$ & 0.096 & 0.28 & $0.06-1.19$ & 0.024 & 6.538 & $1.27-33.54$ \\
\hline Separated parents & $16(26.7)$ & $\begin{array}{c}10 \\
(50.0)\end{array}$ & 0.098 & 2.75 & $0.86-8.92$ & & & \\
\hline \multicolumn{9}{|c|}{ Breastfeeding $\geq 12$ months $(n=81)-$ LRM $(3)$} \\
\hline $\begin{array}{l}\text { Bottle feeding } \\
\text { (onset until } 1^{\text {st }} \text { month) }\end{array}$ & $9(19.1)$ & $18(52.9)$ & & & & & & \\
\hline $\begin{array}{l}\text { Bottle feeding } \\
\text { (onset until } 6^{\text {th }} \text { month) }\end{array}$ & $27(57.4)$ & $30(88.2)$ & 0.006 & 5.56 & $1.52-22.13$ & & & \\
\hline $\begin{array}{l}\text { Pacifier sucking } \\
\text { (onset until } 1^{\text {st }} \text { month) }\end{array}$ & $11(23.40$ & $18(52.9)$ & 0.012 & 3.68 & $1.28-10.74$ & 0.005 & 4.351 & $1.56-12.13$ \\
\hline $\begin{array}{l}\text { Pacifier sucking } \\
\text { (onset until } 3^{\text {rd }} \text { month) }\end{array}$ & $14(29.8)$ & $22(68.8)$ & 0.001 & 5.19 & $1.77-15.59$ & & & \\
\hline $\begin{array}{l}\text { Pacifier sucking } \\
\text { (onset until } 6^{\text {th }} \text { month) }\end{array}$ & $16(34.0)$ & $25(78.1)$ & 0.000 & 6.92 & $2.22-22.39$ & & & \\
\hline $\begin{array}{l}\text { Bottle use } \\
\text { (onset until } 1^{\text {st }} \text { month) }\end{array}$ & $11(23.4)$ & $18(52.9)$ & 0.012 & 3.68 & $1.28-10.74$ & & & \\
\hline $\begin{array}{l}\text { Bottle use } \\
\text { (onset until } 3^{\text {rd }} \text { month) }\end{array}$ & $14(29.8)$ & $23(71.9)$ & 0.001 & 6.02 & $2.02-18.54$ & & & \\
\hline $\begin{array}{l}\text { Bottle use } \\
\text { (onset until } 6^{\text {th }} \text { month) }\end{array}$ & $26(55.3)$ & $28(87.5)$ & 0.006 & 5.65 & $1.54-22.59$ & & & \\
\hline $\begin{array}{l}\text { Maternal age } \\
\text { (> } 35 \text { years) }\end{array}$ & $8(17.0)$ & $0(0.0)$ & Fisher & 0.018 & Indefinido & 0.002 & 0.215 & $0.08-0.58$ \\
\hline
\end{tabular}

LRM: logistic regression model; OR: odds ratio; AOR: adjusted odds ratio 
for cessation of breastfeeding. A study by Mascarenhas et $a l^{(12)}$, involving 940 mothers and babies from one to three months of life, showed that pacifier use poses risk for exclusive breastfeeding. On the other hand, a study by Santiago et $a^{(13)}$, with 101 dyads, followed for four months, found that the non-introduction of pacifier in this period was a protective factor for exclusive breastfeeding. Regarding the use of other artificial nipples until the first month of life, Wayland ${ }^{(14)}$ describes it as a common practice, especially for the introduction of water, tea and juice in children's diet. However, this alone would not characterize non-exclusive breastfeeding ${ }^{(11)}$. Certainly,

Table 2 - Kaplan-Meier bivariate analysis of the factors associated with total breastfeeding duration, Vitória, Brazil, 2007

\begin{tabular}{|c|c|c|c|c|c|}
\hline \multirow[b]{2}{*}{ Variable } & \multirow[b]{2}{*}{ Category } & \multicolumn{2}{|c|}{ Breastfeeding duration } & \multirow[b]{2}{*}{ Log-rank } & \multirow[b]{2}{*}{$p$-value } \\
\hline & & $\begin{array}{c}\text { Mean } \\
(95 \% \mathrm{Cl})\end{array}$ & $\begin{array}{c}\text { Median } \\
(95 \% \mathrm{Cl})\end{array}$ & & \\
\hline \multirow{2}{*}{ Bottle feeding (onset until $1^{\text {st }}$ month) } & Yes & $9(6-13)$ & $4(3-5)$ & \multirow{2}{*}{10.2500} & \multirow{2}{*}{0.0014} \\
\hline & No & $18(16-21)$ & $18(13-23)$ & & \\
\hline \multirow{2}{*}{ Bottle feeding (onset until $6^{\text {th }}$ month) } & Yes & $13(10-16)$ & $10(5-15)$ & \multirow{2}{*}{5.6200} & \multirow{2}{*}{0.0178} \\
\hline & No & $21(18-24)$ & $23(21-25)$ & & \\
\hline \multirow{2}{*}{ Pacifier sucking (onset until $1^{\text {st }}$ month) } & Yes & $12(8-16)$ & $9(3-15)$ & \multirow{2}{*}{2.7600} & \multirow{2}{*}{0.0964} \\
\hline & No & $17(14-20)$ & $18(13-23)$ & & \\
\hline \multirow{2}{*}{ Pacifier sucking (onset until $3^{\text {rd }}$ month) } & Yes & $12(9-15)$ & $9(6-12)$ & \multirow{2}{*}{4.7600} & \multirow{2}{*}{0.0275} \\
\hline & No & $19(16-22)$ & $19(15-23)$ & & \\
\hline \multirow{2}{*}{ Pacifier sucking (onset until $6^{\text {th }}$ month) } & Yes & $12(9-15)$ & $9(6-12)$ & \multirow{2}{*}{7.5200} & \multirow{2}{*}{0.0061} \\
\hline & No & $20(16-23)$ & $19(14-24)$ & & \\
\hline \multirow{2}{*}{ Bottle use (onset until $1^{\text {st }}$ month) } & Yes & $10(6-14)$ & $4(0-10)$ & \multirow{2}{*}{9.8500} & \multirow{2}{*}{0.0017} \\
\hline & No & $18(16-21)$ & $18(10-26)$ & & \\
\hline \multirow{2}{*}{ Bottle use (onset until $3^{\text {rd }}$ month) } & Yes & $10(7-13)$ & $6(2-10)$ & \multirow{2}{*}{18.1100} & \multirow{2}{*}{0.0000} \\
\hline & No & $21(18-23)$ & $23(20-26)$ & & \\
\hline \multirow{2}{*}{ Bottle use (onset until $6^{\text {th }}$ month) } & Yes & $13(10-16)$ & $10(6-14)$ & \multirow{2}{*}{6.8700} & \multirow{2}{*}{0.0087} \\
\hline & No & $22(19-25)$ & $24(23-25)$ & & \\
\hline \multirow{2}{*}{ Monthly family income (in minimum wages) } & $\leq 2$ wages & $17(14-20)$ & $20(13-27)$ & \multirow{2}{*}{3.4400} & \multirow{2}{*}{0.0635} \\
\hline & $>2$ wages & $13(10-16)$ & $12(7-17)$ & & \\
\hline
\end{tabular}

Table 3 - Analysis of factors associated with breastfeeding duration by Cox Regression Models. Vitória, Brazil, 2007

\begin{tabular}{|c|c|c|c|c|c|c|c|c|}
\hline Models & Co-variables & Estimate & $\begin{array}{l}\text { Standard } \\
\text { error }\end{array}$ & Wald & $p$-value & HR & \multicolumn{2}{|c|}{$95 \% \mathrm{Cl}$} \\
\hline \multirow{2}{*}{$\begin{array}{l}\text { Cox regression } \\
(1)^{\star}\end{array}$} & $\begin{array}{l}\text { Bottle feeding } \\
\text { (onset until } 1^{\text {st }} \text { month) }\end{array}$ & 0.89 & 0.27 & 11.23 & 0.00 & 2.43 & 1.45 & 4.10 \\
\hline & $\begin{array}{l}\text { Monthly family income } \\
(<2 \text { minimum wages })\end{array}$ & -0.58 & 0.25 & 5.30 & 0.02 & 0.56 & 0.34 & 0.92 \\
\hline \multirow{3}{*}{$\begin{array}{l}\text { Cox regression } \\
(2)^{*}\end{array}$} & $\begin{array}{l}\text { Bottle feeding } \\
\text { (onset until } 1^{\text {st }} \text { month) }\end{array}$ & 0.70 & 0.28 & 6.26 & 0.01 & 2.01 & 1.16 & 3.47 \\
\hline & $\begin{array}{l}\text { Pacifier sucking } \\
\text { (onset until } 6^{\text {th }} \text { month) }\end{array}$ & 0.54 & 0.26 & 4.27 & 0.04 & 1.72 & 1.03 & 2.88 \\
\hline & $\begin{array}{l}\text { Monthly family income } \\
(<2 \text { minimum wages })\end{array}$ & -0.61 & 0.25 & 5.79 & 0.02 & 0.54 & 0.33 & 0.89 \\
\hline \multirow{2}{*}{$\begin{array}{l}\text { Cox regression } \\
(3)^{\star}\end{array}$} & $\begin{array}{l}\text { Pacifier sucking } \\
\text { (onset until } 6^{\text {th }} \text { month) }\end{array}$ & 0.68 & 0.26 & 7.04 & 0.01 & 1.97 & 1.19 & 3.26 \\
\hline & $\begin{array}{l}\text { Monthly family income } \\
\text { (up to two minimum wages) }\end{array}$ & -0.53 & 0.25 & 4.51 & 0.03 & 0.59 & 0.36 & 0.96 \\
\hline
\end{tabular}

*For the 3 models, the dependent variable analyzed was breastfeeding duration in months. HR: Hazard Ratio 
mothers who reported to make use of these utensils use feed their babies with their own breast milk. However, in possession of these objects, mothers possibly tend to include in the diet foods other than breast milk.

Teeth eruption before the sixth month was associated with cessation of breastfeeding before six months of children's life in LRM (2). It is assumed that the eruption of the first teeth, usually lower central incisors, may represent, for the mother, a risk of getting hurt in their breast nipple during breastfeeding, hampering its maintenance for a prolonged time.

In turn, maternal age higher than or equal to 35 years showed to be a protective factor for breastfeeding for 12 months or more in LRM (3). A study by Oliveira et al ${ }^{(15)}$, using the age 20-34 years as a reference, after adjustment to the analysis model, showed that age below 20 years was the only variable that showed higher risk for cessation of breastfeeding, while age higher than 34 years were not a risk neither a protective factor in babies below 24 months.

In both regression models used, pacifier use, regardless of the period of onset, showed to be an important predictor of breastfeeding duration, except for CRM (1), in which the onset of bottle feeding until the first month annulled the influence of pacifier sucking.

In LRMs (2) and (3), the chances of cessation of breastfeeding were higher at the sixth and the 12th month. In line with this finding, Audi $e t a l^{(16)}$ reported higher chances of abandoning breastfeeding in children who use pacifiers. In CRMs (2) and (3), children who sucked pacifiers showed lower, but significant, risk for cessation of breastfeeding. These findings were similar to some studies ${ }^{(17,18)}$ and very

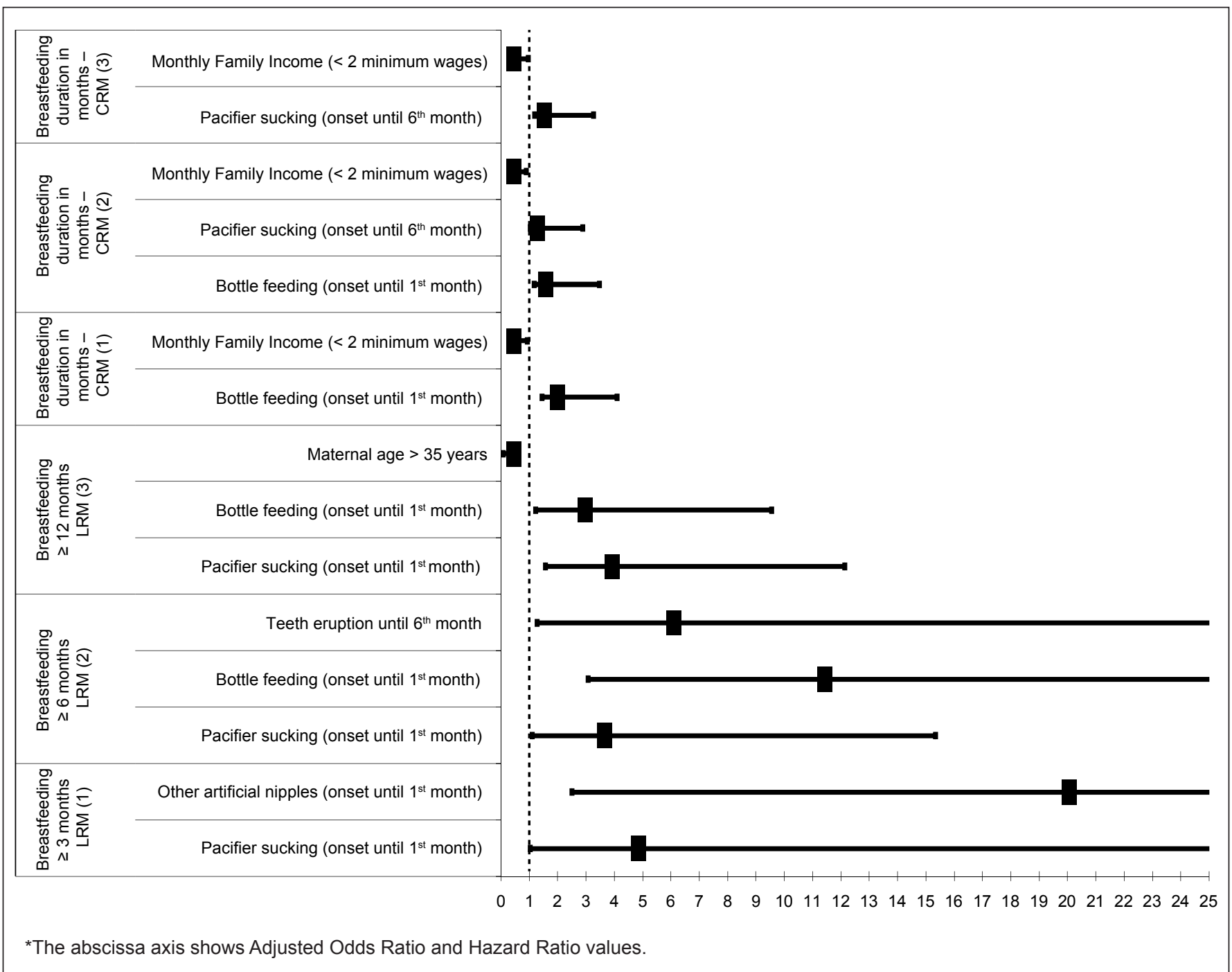

Figure 1 - Analysis of the risk factors associated with cessation of breastfeeding and of protective factors associated to breastfeeding duration by Cox and Logistic Regression models. Vitória, Brazil, 2007 
lower than those observed by Minagawa et al ${ }^{(8)}$ and Silveira and Lamounier ${ }^{(7)}$, showing that, at a higher or lower intensity, pacifier use may be an important factor for cessation of breastfeeding.

Bottle feeding showed to be a risk factor for cessation of breastfeeding in all models, except in CRM (3). It should be considered that the variables bottle feeding and bottle use are very associated; therefore, it was chosen to exclude one of these variables in regression models. Howard $e t a l^{(9)}$ showed that there are differences between the use of glasses and bottles for bottle feeding in breastfeeding duration and that bottle use increases the risk for cessation of breastfeeding, regardless of the type of milk used — of animal origin or industrialized.

In CRMs, income lower to or equal than two minimum wages was an important protective factor for prolonged breastfeeding, which did not occur in LRMs. In LRMs presented by Oliveira $e t$ al $^{(15)}$, populations classified with a low living condition index in Salvador, state of Bahia, Brazil, had higher risk for cessation of breastfeeding than those classified with a high index. Victora $e t l^{(5)}$ analyzed the behavior of this variable using survival tables de in three birth cohorts and showed that, from six to nine months, breastfeeding is more prevalent in families of higher income, but, after 12 months of life, the prevalence of breastfeeding is significantly higher in poorer families.

Based on these observations, it can be concluded that differences in the socioeconomic profile may directly interfere with breastfeeding duration. However, one should consider that the study population does not show great differences regarding social status, because study subjects

\section{References}

1. World Health Organization. The World Health Organization's infant feeding recommendation. Geneva: WHO; 1995.

2. Lamberti LM, Fischer Walker CL, Noiman A, Victora C, Black RE. Breastfeeding and the risk for diarrhea morbidity and mortality. BMC Public Health 2011;11 (Suppl 3):S15.

3. Owen CG, Whincup PH, Kaye SJ, Martin RM, Davey Smith G, Cook DG et al. Does initial breastfeeding lead to lower blood cholesterol in adult life? A quantitative review of the evidence. Am J Clin Nutr 2008;88:305-14.

4. Santos Neto ET, Oliveira AE, Zandonade E, Molina MD. Pacifier use as a risk factor for reduction in breastfeeding duration: a systematic review. Rev Bras Saude Mater Infant 2008;8:377-89.

5. Victora CG, Matijasevich A, Santos IS, Barros AJ, Horta BL, Barros FC. Breastfeeding and feeding patterns in three birth cohorts in Southern Brazil: trends and differentials. Cad Saude Publica 2008;24 (Suppl 3):S409-16. live in socially-deprived areas. Therefore, socioeconomic variables were profile descriptors and control markers. Even though, the small differences in family income influenced breastfeeding duration in CRMs.

It should be highlighted that the follow-up method by period home visits could not establish a strict pattern of time between data collection for all children, because the migratory movement of the families was intense. This is also due to the fact that sample loss was higher than initially planned, although it was not significantly detrimental to the reliability of the results.

The study on risk factors associated with breastfeeding duration is indispensible for the planning and implementation of activities that eliminate their effects on breastfeeding practice. Additionally, the use of different statistical analysis methods may lead to more detailed results, with the visualization of peculiarities from different angles, revealing specific results that, although are not identical, are not contradictory either. This possibly occurs because LRMs analyzed dichotomously the fact that the child is being breastfed or not at the first, sixth or $12^{\text {th }}$ month. At these time points, it is understood that contextual factors compel to children's weaning. In turn, in CRMs, the factors that boosted cessation of breastfeeding are analyzed as if they were present all the time during child's life until weaning.

This study also suggests that it is necessary to fight against the use of pacifiers and early bottle feeding, in order to favor the practice of breastfeeding for an appropriate period of time, enabling the comprehensive promotion of children's health since their first years of life.

6. Mikiel-Kostyra K, Mazur J, Wojdan-Godek E. Factors affecting exclusive breastfeeding in Poland: cross-sectional survey of population-based samples. Soz Praventivmed 2005;50:52-9.

7. Silveira FJ, Lamounier JA. Factors associated with breastfeeding duration in three cities in the region of Alto Jequitinhonha, Minas Gerais, Brazil. Cad Saude Publica 2006;22:69-77.

8. Minagawa AT, Oliveira IM, Fujimori E, Laurenti D, Montera RM. Profile of breastfeeding in children under 2 years old in the city of itupeva, SP, Brazil. Arch Latinoam Nutr 2005;55:132-9.

9. Howard CR, Howard FM, Lanphear B, Eberly S, deBlieck EA, Oakes D et al. Randomized clinical trial of pacifier use and bottle-feeding or cupfeeding and their effect on breastfeeding. Pediatrics 2003;111:511-8.

10. Prefeitura Municipal de Vitória: uma cidade melhor para todos [homepage on the Internet]. Vitória: Plano Municipal de Saúde [cited 2012 Dec 7]. Available from: http://www.vitoria.es.gov.br/semus.php 
11. Kramer MS, Kakuma R. Optimal duration of exclusive breastfeeding. Cochrane Database Syst Rev 2002;(1):CD003517.

12. Mascarenhas ML, Albernaz EP, Silva MB, Silveira RB. Prevalence of exclusive breastfeeding and its determiners in the first 3 months of life in the South of Brazil. J Pediatr (Rio J) 2006;82:289-94.

13. Santiago LB, Bettiol H, Barbieri MA, Guttierrez MR, Del Ciampo LA. Promotion of breastfeeding: the importance of pediatricians with specific training. J Pediatr (Rio J) 2003;79:504-12.

14. Wayland C. Breastfeeding patterns in Rio Branco, Acre, Brazil: a survey of reasons for weaning. Cad Saude Publica 2004;20:1757-61.

15. Oliveira LP, Assis AM, Gomes GS, Prado MS, Barreto ML. Breastfeeding duration, infant feeding regimes, and factors related to living conditions in the city of Salvador, Bahia, Brazil. Cad Saude Publica 2005;21:1519-30.

16. Audi CA, Corrêa AM, Latorre MR. Complementary feeding and factors associated to breast-feeding and exclusive breast-feeding among infant up to 12 months of age, Itapira, São Paulo, 1999. Rev Bras Saude Mater Infant 2003;3:85-93.

17. Giovannini M, Riva E, Banderali G, Scaglioni S, Veehof SH, Sala M et al. Feeding practices of infants through the first year of life in Italy. Acta Pædiatr 2004;93:492-7.

18. Aarts C, Hörnell A, Kylberg E, Hofvander Y, Gebre-Medhin M. Breastfeeding patterns in relation to thumb sucking and pacifier use. Pediatrics 1999;104:e50. 